\title{
Data envelopment analysis for planning emergency
}

\author{
F. Russo \& C. Rindone \\ Università degli Studi Mediterranea di Reggio Calabria, \\ DIMET, Dipartimento di Informatica, \\ Matematica, Elettronica e Trasporti, Italy
}

\begin{abstract}
In this paper an evaluation of methods to compare evacuation plans is proposed. The method is based on the assumption that an evacuation is represented by means of a production process fed by a set of inputs that are combined to obtain a set of outputs. A non-parametric method and, in particular, a Data Envelopment Analysis (DEA), is presented. The framework is that the production function of fully efficient firms is unknowable. An application to compare the possible impacts of various hurricane hazards is presented. Constant Return of Scale hypothesis is adopted.

Keywords: evacuation planning, evaluation methods, DEA.
\end{abstract}

\section{Introduction}

Transportation planning is finalised to define a transportation system and relative infrastructures and services, in specific forecasting scenario. Transportation planning concerns both ordinary and emergency conditions and internal and external planning process. In this paper we consider the internal transportation planning process in emergency conditions.

Transportation planning in emergency conditions aims to specify interventions to reduce risk. Risk has three main components:

- occurrence, related to event probability or frequency;

- vulnerability, related to the resistance of the infrastructures when the effect of the event has occurred;

- exposure, related to the weighted value of people, goods and infrastructures affected during and after the event. 
The main measure to reduce exposure is evacuation, which consists of reducing the number of users and goods that can experience negative effects when emergency events occur $[1,2]$.

The evaluation of methods for planning, allow for a comparison of the effects of different plans in respect of one or more criteria. Single elements of an evacuation plan can be evaluated by means of specific indicators. Based on these indicators, different evacuation plans can be compared in ex ante and in ex post conditions. Analysis of single indicators can give different results. For this reason it is necessary to adopt evaluation methods that allow us to consider contemporaneously all the known indicators (performance measures).

Measures can be quantitative or qualitative and direct or indirect (proxy variables). Indicators are functions to synthetize available information and have to be defined for each plan component.

In some countries, the planning process in emergency conditions, and relative evaluation methods, are carried out according to rules and/or standards.

In Australia, a framework for measuring the performance of emergency management is defined. The approach involves three levels of elements [3]: objectives to achieve; performance criteria to measure how each objective is achieved; acceptable solutions to provide as examples of what may enable achievement of the performance criteria.

Nakanishi et al. [4] propose a set of performance indicators, which measure the achievement of emergency preparedness goals and policies of a transit agency.

Some authors $[5,6]$ propose a multi-objective optimization approach for evacuation planning; the authors indicate a set of Measures of Effectiveness to improve evacuation process, that consider other factors in respect of traditional evacuation times.

Some authors adopt specific performance in designing methods for specific components of transportation systems in evacuation conditions based on specific performances $[7,8]$.

In this paper, an evaluation method, based on efficiency criterion, is proposed. The method is based on the assumption that an evacuation is represented by means of a production process fed by a set of inputs that are combined to obtain a set of one or more outputs. Performances of this process are measured in terms of efficiency.

In literature several methods to measure efficiency are available. A possible classification of these methods is based on the production function:

- $\quad$ parametric methods, based on the assumption that the production function of fully efficient firms is known [9, 10];

- non-parametric methods, based on the assumption that the production function of fully efficient firms is not known; in this class, some methods are DEA $[10,11]$ and Free Disposal Hull (FDH) $[12,13]$.

In this paper a DEA non parametric method is proposed to compare evacuation planning.

The paper is structured as follows: in Section 2, DEA in transportation planning is recalled and in Section 3 specific reference evacuation planning is 
reported; in Section 4, a prototypal application of DEA to compare evacuation plans is presented.

\section{DEA in transportation planning}

DEA was originally introduced to evaluate production efficiency in industrial systems, where inputs are labour, energy and capital resources and outputs are goods or services. Starting from Farrell's definition of efficiency [14], the first formulation of DEA was introduced by Charnes et al. [11]. This formulation was based on the hypothesis of Constant Returns to Scale (CRS). An extension of the CRS model has been proposed by Banker et al. [15], in which the CRS hypothesis is removed and Variable Returns to Scale (VRS) decreasing or increasing are admitted.

DEA is based on technical efficiency concept that measures capacity of a Decision Making Unit (DMU) to realize a productive process that combine production factors (input) to obtain a product (output). Then, each DMU is represented by means of a set of one, or more, inputs and a set of one, or more, outputs.

Defining the space of input variables $\left(\mathrm{R}^{\mathrm{r}}\right)$ and output variables $\left(\mathrm{R}^{\mathrm{s}}\right)$, each DMU can be allocated in a point representative of his efficiency belonging to the space $\mathrm{R}^{(\mathrm{r} U \mathrm{~s})}$.

Efficient DMU belong to the frontier. The distance from this frontier is a measure of inefficiency of a DMU, that could be eliminated through a variation in quantity of inputs (input-oriented) or outputs (output-oriented) or both (additive model) [16].

Time variation of efficiency measures, is considered according to different approaches. Common approaches presented in literature are: contemporaneous approach; intertemporal approach; sequential approach; windows analysis $[17,18]$. These approaches differ on construction of observation set into different temporal periods.

DEA has subsequently been applied in many fields of economics and engineering [19]. General works regard the decision making process in the phases of selection and ranking of alternative scenarios [20-23]. Specific works using the DEA approach to analyse different components of the transportation system have been produced regarding: urban transport systems [24, 25], air transport systems [26], railways systems [27, 28], container maritime transport at an international scale [29].

\section{DEA in evacuation planning}

In literature, few studies applying DEA to compare evacuation plans have been developed [30, 31].

To apply DEA for comparing evacuation plans it is necessary to define evacuation planning process in terms of inputs and outputs. The selection of inputs and outputs depends on available data about evacuation and depends on the approach adopted to analyse the evacuation process. 
Two different levels of simulation are possible. The classical one for which all the people are physically evacuated from the (considered) exposed area and a computer simulation approach on which the behaviour of users is modelled [32] leaving from specific hypothesis, for instance fuzzy choice [33], and the supply is modelled by means of a topological approach [34, 35].

If the evacuation process is analysed adopting a simulation approach (both physical and computer):

- inputs can be selected from variables that fed simulation models,

- elements to represent demand components, for instance estimated population to evacuate, occasional and systematic users in the study area;

- elements to represent supply components, for instance the total amount of urban road network extension or the total amount of available surfaces for the refuge area, or the average distance from the refuge area, or available emergency vehicles $[36,38]$;

- outputs can be selected from variables resulting from simulation models; for instance, output variables can be evacuation times estimated adopting simulation models [39, 40], or measured in the field [41-45].

If the evacuation process is analyzed, adopting exercises approach inputs and output can be selected from the same variables estimated in the simulation approach that are measured by means of monitoring models.

\section{A prototypal application}

In this paper an application of DEA to compare evacuation plans is presented. The application is finalised to obtain frontier efficiency starting from available data.

A database is obtained from results of a study published from the US Army Corps of Engineers (USACE) to analyze the possible impacts of various hurricane hazards in the State of Maine [46]. Data are relative to ten counties $\left(\mathrm{DMU}_{\mathrm{i}}\right)$ for which data are available. The study reports data relative to counties in which the State is subdivided (Table 1).

Starting from the full database, which comprehends all available information, in order to represent evacuation process of each county, the following data are selected data:

- $\quad$ evacuation process inputs; data are obtained from database of the Decennial Census taken by the US Census Bureau for the year 2000 and are relative to permanent population and vehicles evacuating;

- evacuation process outputs; data are expressed in terms of estimated clearance times by evacuation scenario.

CRS DEA methods specification is adopted. Two applications are carried out representing evacuation process by means of:

a) one input (permanent population) and one output (clearance times);

b) one input (vehicle evacuating) and one output (clearance times). 
Table 1: $\quad$ Available data (source USACE 2007 [46]).

\begin{tabular}{ccccc}
\hline County & $\begin{array}{c}\text { Permanent } \\
\text { population } \\
\text { (inab.*100,000) } \\
\text { input }\end{array}$ & $\begin{array}{c}\text { Vehicles } \\
\text { evacuating } \\
\text { (car*10,000) } \\
\text { input }_{2}\end{array}$ & $\begin{array}{c}\text { Clearance } \\
\text { time } \\
\text { (hours) } \\
\text { output }\end{array}$ \\
\cline { 2 - 5 } 1 & Cumberland & 2.79 & 9.1 & 2.75 \\
2 & Hancock & 0.55 & 6.4 & 3.75 \\
3 & Kennebec & 1.22 & 5.5 & 2.75 \\
4 & Knox & 0.42 & 2.8 & 4.00 \\
5 & Lincoln & 0.36 & 3.6 & 1.75 \\
6 & Penobscot & 1.50 & 7.7 & 3.00 \\
7 & Sagadahoc & 0.38 & 2.0 & 1.75 \\
8 & Waldo & 0.40 & 3.1 & 6.25 \\
9 & Washington & 0.33 & 3.1 & 4.00 \\
10 & York & 2.07 & 16.8 & 1.75 \\
\hline
\end{tabular}

In both applications, the most efficient county has the minimum ratio between outputs and inputs. In fact, reducing clearance time, the exposure risk component decreases. The frontier is represented from a straight line passing from the origin and angular coefficient equal to the minimum output/input ratio. To modify inefficiency of some counties, evacuation times have to be reduced.

a) Permanent population and clearance times

Considering an evacuation process characterised by one input and one output, it results that York County is the most efficient; it has the minimum value of output/input ${ }_{1}$ 0.85. Then the frontier has the following form:

$$
\text { clearance time }(\mathrm{a})=0.85 * \text { permanent population }
$$

To report the other counties at efficiency similar to the best one, different steps can be developed. For instance, to improve Lincoln County performance, different models can be used. The considered models are (Tab. 2):

a1) reduced clearance times to reach the frontier with the same permanent population;

a2) increased permanent population to reach the frontier with the same clearence time;

a3) reduced clearance time and increased permanent population to reach the frontier.

b) Vehicle evacuating and clearance times

Considering an evacuation process characterised by one input (vehicle evacuating) and one output (clearance times), it results that York County is again, the most efficient one; it has the minimum value of output/input ${ }_{2} 0.10$. Then the frontier has the following form:

$$
\text { clearance time }(b)=0.10 * \text { vehicles evacuating }
$$

also in this case it is possible to underline the hypothetical improvement that the other counties could implement. For instance, to improve Lincoln County 
performance, different models can be used. The considered models are (Tab. 2):

b1) reduced clearance time has to reach the frontier with the same vehicles evacuating;

b2) increased vehicle evacuating to reach the frontier with the same clearance time;

b3) reduced clearance time and increased vehicles evacuating.

Table 2: CRS method: one input, one output results.

\begin{tabular}{|c|c|c|c|c|c|c|c|c|c|c|c|}
\hline & \multirow[t]{2}{*}{ County } & \multirow[t]{2}{*}{$\begin{array}{c}\text { output/ }_{\text {input }} \\
\text { ( }\end{array}$} & \multirow[t]{2}{*}{$\begin{array}{l}\text { output/ }_{\text {input }} \\
\text { (1) }\end{array}$} & \multicolumn{2}{|c|}{$\begin{array}{c}\text { Permanent } \\
\text { population } \\
\text { (inab.*100,000) }\end{array}$} & \multicolumn{2}{|c|}{$\begin{array}{c}\text { Vehicles } \\
\text { evacuating } \\
\text { (car*10,000) }\end{array}$} & \multicolumn{4}{|c|}{$\begin{array}{c}\text { Clearance time } \\
\text { (hours) }\end{array}$} \\
\hline & & & & (a2) & (a3) & (b2) & (b3) & (a1) & (a3) & (b1) & (b3) \\
\hline 1 & Cumberland & 0.98 & 0.30 & 3.24 & 2.98 & 27.5 & 9.3 & 2.36 & 2.53 & 0.91 & 0.96 \\
\hline 2 & Hancock & 6.84 & 0.59 & 4.41 & 2.17 & 37.5 & 6.7 & 0.46 & 1.84 & 0.64 & 0.70 \\
\hline 3 & Kennebec & 2.25 & 0.50 & 3.24 & 2.07 & 27.5 & 5.7 & 1.03 & 1.75 & 0.55 & 0.60 \\
\hline 4 & Knox & 9.55 & 1.43 & 4.71 & 2.22 & 40.0 & 3.2 & 0.36 & 1.88 & 0.28 & 0.33 \\
\hline 5 & Lincoln & 4.82 & 0.49 & 2.06 & 1.07 & 17.5 & 3.8 & 0.31 & 0.91 & 0.36 & 0.39 \\
\hline 6 & Penobscot & 2.00 & 0.39 & 3.53 & 2.35 & 30.0 & 7.9 & 1.27 & 1.99 & 0.77 & 0.82 \\
\hline 7 & Sagadahoc & 4.59 & 0.88 & 2.06 & 1.08 & 17.5 & 2.2 & 0.32 & 0.92 & 0.20 & 0.22 \\
\hline 8 & Waldo & 15.82 & 2.02 & 7.35 & 3.31 & 62.5 & 3.7 & 0.34 & 2.81 & 0.31 & 0.39 \\
\hline 9 & Washington & 12.08 & 1.29 & 4.71 & 2.17 & 40.0 & 3.5 & 0.28 & 1.84 & 0.31 & 0.36 \\
\hline 10 & York & 0.85 & 0.10 & 2.07 & 2.07 & 16.8 & 16.8 & 1.75 & 1.75 & 1.75 & 1.75 \\
\hline
\end{tabular}

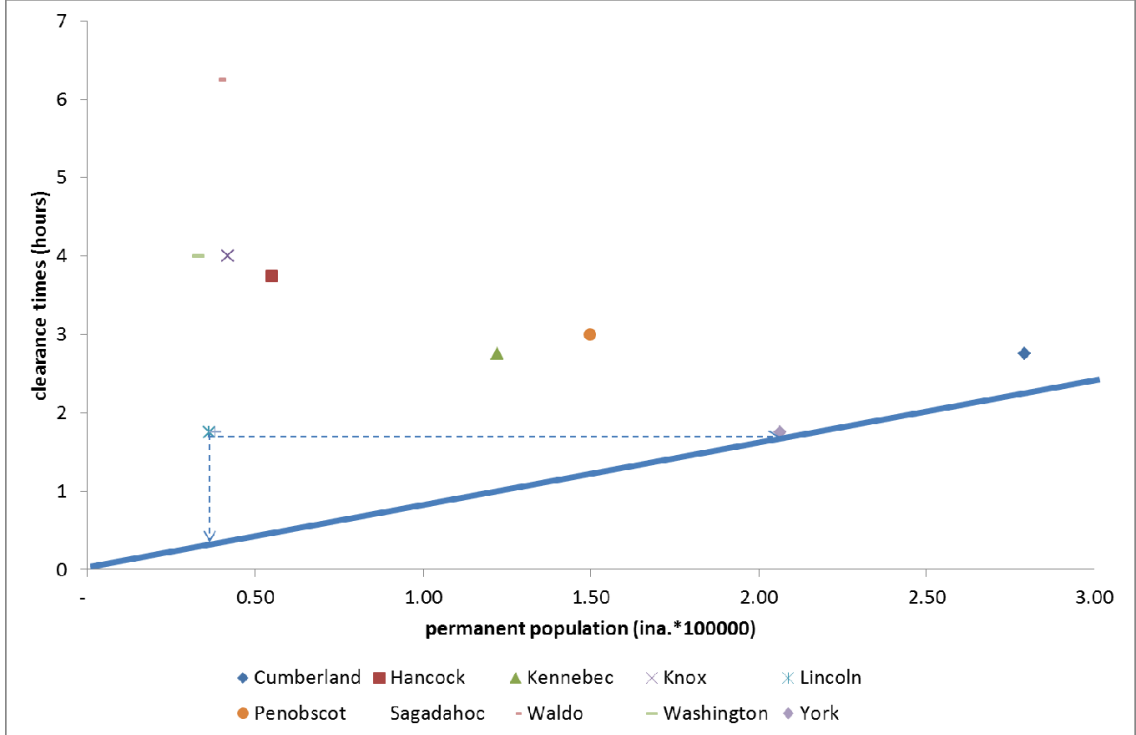

Figure 1: One input (permanent population) and one output (clearance times). 
Non-parametric methods compare efficiency of an evacuation process with respect to a frontier production function that depends on the set of cities considered. This means that if the set changes, then the measure of efficiency can be different.

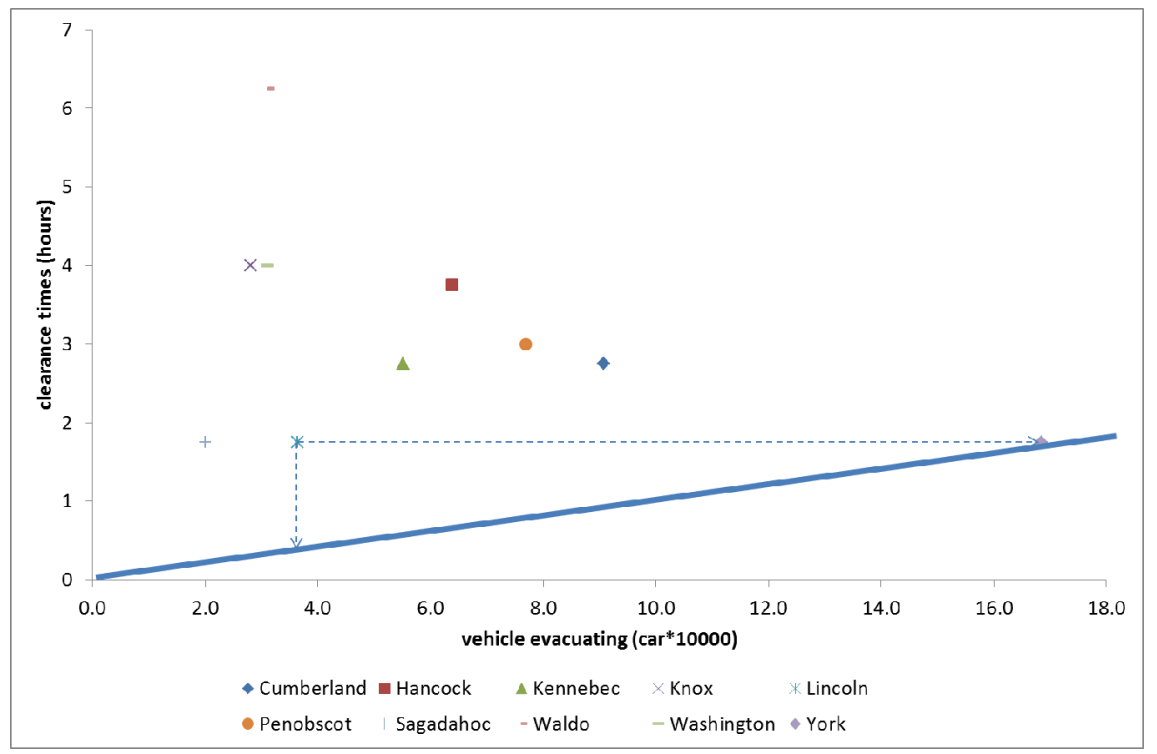

Figure 2: One input (vehicle evacuating) and one output (clearance times).

Easy results of DEA applications presented in this paper show that efficiency of evacuation plans varies with DEA method formulation and subset of considered data. The type of input and output selected influence the frontier. In the specific case considered in the application presented in this paper, other elements, that influence organisation of an evacuation, have to be considered. For instance, the distance between evacuation area and safe area has to be considered to explain the high value of evacuation times.

\section{References}

[1] Russo F. and Vitetta A., Risk evaluation in a transportation system. International Journal of Sustainable Development and Planning, 1 (2), pp. 170-191, 2006.

[2] Russo F. and Vitetta A., Safety of users in road evacuation: General methodology and main results. Proc. of Urban Transport XIII, Urban Transport and the Environment in the 21st century, Brebbia C. A. (ed.), WIT Press, Southampton, pp. 763-772, 2007.

[3] Australian Government, Australian Emergency Management http://www.em.gov.au/Emergencymanagement/Pages/default.aspx 
[4] Nakanishi Y., Kim K. and Ulusoy Y. (2003), Assessing emergency preparedness of transit agencies: a focus on performance indicators, Proc. of TRB Annual Meeting, 2003.

[5] Han L. D., Yuan F. and Urbanik T., What Is an Effective Evacuation Operation?, Journal of urban planning and development, ASCE, 2007.

[6] Yuan, F. and Han L.D., A Multi-Objective Optimization Approach for Evacuation Planning, Procedia Engineering, Vol. 3, pp. 217-227, 2010.

[7] Polimeni A., Quattrone A. and Vitetta A., An approach to designing vehicle routes in evacuation conditions. WIT Transactions on Ecology and the Environment, Volume 141, Risk analysis VII \& Brownfields V, Brebbia C. A. (ed.), WIT Press, Southampton, pp. 469-480, 2010.

[8] Polimeni A. and Vitetta A., Dynamic vehicle routing in road evacuation: a model for route design. WIT Transactions on the Built Environment, Volume 116, Urban Transport XVII, Urban Transport and the Environment in $21^{\text {st }}$ Century, Pratelli and Brebbia C. A. (ed.), WIT Press, Southampton, pp. 627-638, 2011.

[9] Aigner, D., Lovell, K. and Schmidt, P. (1977), Formulation and estimation of stochastic frontier models, Journal of Econometrics 6 (1), pp. 21-37.

[10] Coelli, T., Rao, D. S. P. and Battese, G., E. (1998), An Introduction to Efficiency and Productivity Analysis, Kluwer Academic Publishers.

[11] Charnes, A., Cooper, W.W. and Rhodes E., Measuring the efficiency of decision making units, European Journal of Operational Research 2 pp. 429-444, 1978.

[12] Deprins, D., Simar, L. and Tulkens, H. (1984), Measuring labour efficiency in post offices, In: Marchand, M., Pestieau, P. \& Tulkens, H. (Eds.), The Performance of Public Enterprises Concepts and Measurements, Elsevier, pp. 247-263.

[13] Lovell, C.A.K. and Eeckaut P. V. (1993), Frontier Tales: DEA and FDH, Mathematical Modeling in Economics, W.E. Diewert, K. Spremann, and F. Steling (ed.), Physica-Verlag, Berlin, pp. 446-457.

[14] Farrell, M. J., The measurement of productive efficiency, Journal of the Royal Statistical Society A 120 pp. 253-281, 1957.

[15] Banker R.D., Charnes A. and Cooper W.W. (1984), Some models for estimating technical and scale inefficiencies in data envelopment analysis, Management Science 30, pp. 1078-1092.

[16] Cooper, W.W., Seiford, L.M. and Tone, K., Data Envelopment Analysis, Kluwer Academic Publisher, Boston, USA, 2000.

[17] Charnes, A. Clark, C. T. Cooper, W. W. and Golany, B., A Developmental Study of Data Envelopment Analysis in Measuring the Efficiency of Maintenance Units in the U.S. Air Forces, Annals of Operation Research, 2, pp. 95-112, 1985.

[18] Cullinane K. P. B. and Wang T., Data Envelopment Analysis (DEA) and Improving Container Port Efficiency, in Brooks M.R. and Cullinane K.P.B. (eds) Port Governance and Performance, Research in Transportation Economics, Vol. 17, Elsevier: London, pp. 517-566, 2007. 
[19] Tavaresa, G., A bibliography of data envelopment analysis (1978-2001), Rutcor Research Report, Rutgers University, Center for Operations Research, New Jersey, USA, 2002.

[20] Cook W. D. and Green, R. H., "Project prioritization: a resourceconstrained data envelopment analysis approach", Socio-Economic Planning Sciences, 34, pp. 85-99, 2000.

[21] Tsamboulas D. and Mikroudis G., EFECT: evaluation framework of environmental impacts and costs of transport initiatives, Transportation Research Part D: transport and environment 5, pp. 283-303, 2000.

[22] Bernroider E.W.N. and Stix V., Profile distance method: a multi-attribute decision making approach for information system investments. Decision Support Systems 42, pp. 988-998, 2006.

[23] Lahdelma R. and Salminen P., Stochastic multicriteria acceptability analysis using the data envelopment model, European Journal of Operational Research 170, pp. 241-252, 2006.

[24] Nozick, L. K., Borderas H. and Meyburg A. H., Evaluation of travel demand measures and programs: A data envelopment analysis approach, Transportation Research Part A: Policy and Practice 32(5), pp. 331-343, 1998.

[25] Odeck, J., Congestion, ownership, region of operation, and scale: Their impact on bus operator performance in Norway, Socio-Economic Planning Sciences 40, pp. 52-69, 2006.

[26] Lupi M. and Danesi A., Valutazione globale delle performance aeroportuali: applicazione della Data Envelopment Analysis (DEA) agli aeroporti italiani, in Linee guida per la programmazione dello sviluppo degli aeroporti regionali. Lupi M. (ed.), FrancoAngeli, Milan, Italy. pp. 181-210, 2007.

[27] Oum, TH., WG. Waters, and C. Yu (1999), A Survey of productivity and efficiency measurement in Rail transport, Journal of Transport Economics and Policy, 33, pp. 9-44.

[28] Graham D. J. (2008), Productivity and efficiency in urban railways: Parametric and non-parametric estimates, Transportation Research Part E 44 pp. 84-99.

[29] Russo F. and Rindone C., Container maritime transport at international scale: Data Envelopment Analysis for transhipment port. WIT Transactions on the Built Environment, Volume 150, Proc. of Sustainable Development and Planning V, Brebbia C. A. (ed.), WIT Press, Southampton, Boston, 2011.

[30] Russo F. and Rindone C., Evaluation methods for evacuation planning. WIT Transactions on the Built Environment, Volume 111, Urban Transport XVI, Urban Transport and the Environment in the 21st century, Brebbia C. A. (ed.), WIT Press, Southampton, pp. 335-343, 2010.

[31] Russo, F. and Rindone C., Data Envelopment Analysis (DEA) for evacuation planning. WIT Transactions on Ecology and the Environment, Volume 141, Risk analysis VII \& Brownfields V, Brebbia C. A. (ed.), WIT Press, Southampton, pp. 455-467, 2010. 
[32] Russo F. and Chilà G., Safety of users in road evacuation: demand models. WIT Transactions on the Built Environment, Volume 96, Urban Transport XIII, Urban Transport and the Environment in the 21st century, Brebbia C. A. (ed.), WIT Press, Southampton, pp. 773-782, 2007.

[33] Quattrone A. and Vitetta A., Random and fuzzy utility models for road route choice. Transportation Research Part E: Logistics and Transportation Review, Volume 47, Issue 6, pp. 1126-1139.

[34] Vitetta A., Musolino G. and Marcianò F.A., Safety of users in road evacuation: Supply and demand-supply interaction models for users. WIT Transactions on the Built Environment, Volume 96, Urban Transport XIII, Urban Transport and the Environment in the 21st century, Brebbia C. A. (ed.), WIT Press, Southampton, pp. 783-792, 2007.

[35] Vitetta A., Musolino G. and Marcianò F. A., Safety of users in road evacuation: calibration of cost functions and simulation. WIT Transactions on the Built Environment, Volume 101, Urban Transport XIV, Urban Transport and the Environment in the 21st century, Brebbia C. A. (ed.), WIT Press, Southampton, pp. 715-725, 2008.

[36] Vitetta A., Quattrone A. and Polimeni A., Safety of users in road evacuation: design of path choice models for emergency vehicles. WIT Transactions on the Built Environment, Volume 96, Urban Transport XIII, Urban Transport and the Environment in the 21st century, Brebbia C. A. (ed.), WIT Press, Southampton, pp. 803-812, 2007.

[37] Vitetta A., Quattrone A. and Polimeni A., Safety of users in road evacuation: algorithms for path design of emergency vehicles. WIT Transactions on the Built Environment, Volume 101, Urban Transport XIV, Urban Transport and the Environment in the 21st century, Brebbia C. A. (ed.), WIT Press, Southampton, pp. 727-737, 2008.

[38] Vitetta A., Quattrone A. and Polimeni A., Safety of users in road evacuation: Modelling and DSS for paths design of emergency vehicles. WIT Transactions on Ecology and the Environment, Volume 120, Sustainable Development and Planning IV, vol.1, Brebbia C. A. (ed.), WIT Press, Southampton, pp. 485-495, 2009.

[39] Vitetta A., Musolino G. and Marcianò F.A., Safety of users in road evacuation: Modelling and DSS for transport supply and supply-demand interaction. WIT Transactions on Ecology and the Environment, Volume 120, Sustainable Development and Planning IV, vol.1, Brebbia C. A. (ed.), WIT Press, Southampton, pp. 475-484, 2009.

[40] Musolino G. and Vitetta A., Short-term forecasting in road evacuation: calibration of a travel time function. WIT Transactions on the Built Environment, Volume 116, Urban Transport XVII, Urban Transport and the Environment in $21^{\text {st }}$ Century, Pratelli and Brebbia C. A. (ed.), WIT Press, Southampton, pp. 615-626, 2011.

[41] Marcianò F.A., Musolino G. and Vitetta A., A system of models for signal setting design of a signalized road network in evacuation conditions. WIT Transactions on the Built Environment, Volume 111, Urban Transport XVI, 
Urban Transport and the Environment in the 21st century, Brebbia C. A. (ed.), WIT Press, Southampton, pp. 313-323, 2010.

[42] Marcianò F.A, Musolino G. and Vitetta A., Signal setting design on a road network: application of a system of models in evacuation conditions. WIT Transactions on Ecology and the Environment, Volume 141, Risk analysis VII \& Brownfields V, Brebbia C. A. (ed.), WIT Press, Southampton, pp. 443-454, 2010.

[43] Marcianò F.A., Musolino G. and Vitetta A., Within day traffic assignment and signal setting in road evacuation: a procedure with explicit path enumeration. WIT Transactions on the Built Environment, Volume 117, Safety and Security engineering IV, Guarascio M., Reiners G. Brebbia C. A. and Garzia F. (ed.), WIT Press, Southampton, pp. 403-414, 2011.

[44] Polimeni A., Quattrone A. and Vitetta A., A tool for tracing emergency vehicles during evacuation. WIT Transactions on the Built Environment, Volume 111, Urban Transport XVI, Urban Transport and the Environment in the 21 st century, Brebbia C. A. (ed.), WIT Press, Southampton, pp. 325333, 2010.

[45] Polimeni A. and Vitetta A., Dynamic vehicle routing in road evacuation: route design experimentation. WIT Transactions on the Built Environment, Volume 117, Safety and Security engineering IV, Guarascio M., Reiners G. Brebbia C. A. \& Garzia F. (ed.), WIT Press, Southampton, pp. 391-402, 2011.

[46] U.S. Army Corps of Engineers (USACE), Maine Hurricane Evacuation Study. Transportation Analysis - 2007 http://www.nae.usace.army.mil/ projects/hurricanemaps/mainesumreport.pdf, last access November 2011. 